\title{
Factors that Influence the Adoptions of Internet Banking Among Customers
}

\author{
Muhammad Azimulhakim Bin Haji Saman \\ Master Student \\ Faculty of Islamic Economics and Finance \\ Islamic University of Sultan Sharif Ali \\ Negara Brunei Darussalam \\ Email: azimul2093@gmail.com
}

Received: December 5, 2018

Accepted: December 11, 2018

Online Published: December 18, 2018

\begin{abstract}
Internet banking is the latest technology that has revolutionized the changes of banking and business systems around the world. However, arrival of technology has an impact on Internet banking and transforms from a traditional banking system to a very useful innovation technology. The purpose of this study is to analyze factors that have influenced users to use Internet banking in doing financial transaction. This study uses content analysis on the previous literatures. The findings showed that there were 10 main different factors which influence the adoption of internet banking by the users. This study also proved that the highest factors which consist of 2 main factors are generated from technology acceptance model (TAM). Contribution of this research are significantly helps bank to have a better understanding on factors that influence the adoption of internet banking as well as help to develop a strategy to improved internet banking services.
\end{abstract}

Keywords: Customer's Adoption, Influence Factors, Internet Banking.

JEL Classification: G21; G40; I22; J16; O32; 035

\section{Introduction}

Technology has provided many benefits and facilities that have been affecting the banking sector and because of that banks have invested heavily in technology as its benefits contribute greatly to progress and provide faster banking services to customers (Heinonen 2006; Laukkanen 2007). In addition, internet technology has not only made substantial changes to the banking system but also improved business performance.

In the era of globalization today, the advancement of internet technology has been fully utilized by many companies to influence their customers in applying what has been provided by a sector. However, it has become an important measure of the success or effectiveness of users' use of technology. The development of information and communication technology over the past 20 years has had a different impact on businesses and individuals. Therefore, internet banking is a technological innovation that plays an important role in changing the structure and nature of banking (Shazili et al, 2014).

According to different perspectives, Mckechnie et.al (2006) \& Mekter et.al (2003) have concluded that internet banking, Automatic Teller Machine (ATMs), an electronic business is one of the most popular forms of selfservice technology. However, although customers can see the benefits of using them, there are still users who refuse to use them if they are not comfortable applying them. This matter has been one of the factors that banking industry still has a problem in return for investment in technology as not all customers can receive internet banking. However, Melek et.al (2010) has stated that the majority of users can receive internet banking well, especially for educated people. Hence, Internet banking has been increasingly intensified for the sake of making use Internet banking thoroughly.

The purpose of this study is to examine the factors that have influenced the user in using internet banking. This study helps identify the main factors that influence the adoption of internet banking. From theoretical perspectives, the result contributes to an existing literature where this article helps provide an amendment factor that may influence the customer to use internet banking. From a practical implications, this research is significantly contributes to banking sector or bank managers to have a better understandings toward internet banking as well as help banks to develop strategies to enhance Internet banking services and usage. The banks also able to specified certain budget on which factor should bank invest more so that the internet banking 
services are more likely able to use to all age categories and increase bank marketing especially on online services.

The rest of the paper will discuss some definitions of internet banking as an explanation of the essence of this study. This study also highlight on demographic impacts that also play a role in influencing users to use internet banking. It addresses the user's ability to adapt internet banking before switching to the main issue of the study, which is the factor of encouraging users to apply internet banking. The discussion will be ended with conclusions and recommendations.

2. Concepts of Internet banking

Driga (2014) defines internet banking as an online banking online which uses a website that is a more advanced banking method, a system that allows bank customers to access accounts and find out general information about bank products and services directly through personal computers, mobile phones and others as delivery channels. According to Oliveira et.al (2014) says internet banking is an instance commerce that used through mobile device which enables the customer to adapt financial transaction through mobile. In addition, customers can access all their accounts via banking website and are allowed to run banking transactions such as bill payment, sale and purchase transaction and others.

According to Maitlo (2015) internet banking is one of the conventional phases in bank services. Online banking allows banks to increase their operations by lowering cost rates more effectively to transform the traditional banking system into online banking. Shaikh \& Karjaluoto (2015) states that internet banking is a product or service offered by bank or microfinance institutions that used to make transaction using an intelligent devices namely as mobile phone smartphones or tablet. In the current era, by using online banking, it can provide convenience in conducting banking transactions and easily obtain information related to transactions without having to go to a branch bank to conduct transactions such as seeing bank account balance, utility bill payment and so on. The majority of banks have introduced the electronic banking system as more advanced and information systems help customers interact well, quickly and easily.

According to Pace (2016) internet banking is an online banking that allows its users to conduct several banking activities that are usually carried out on a banking factor and transactions conducted using the internet while according to Koksal (2016) says that internet banking is able to use in any kind of banking activities that carried out through mobile devices as a personal digital assistant. Thus, internet banking is also a platform that is often used for banking. Some types of services provided by the customer by the bank and show that anyone can make transactions such as financial entry or business anywhere they are either a computer or a mobile phone.

3. The ability of users to adlapt Internet banking

The number of users with access to the Internet is one of the determinants of the level of use of internet banking services. Some issues related to user account security may also distract consumers from using the facilities available in Internet banking. It changes from social psychological and research aspects that differ from those in which the user feels more comfortable with the user relationship with the face-to-face banking expert. Therefore, users who seek social benefits and psychological benefits through their personal relationships with the banking community prefer to meet face-to-face with banking experts. But some users are able to apply internet banking as a renewal to the banking method.

Reynolds \& Betty (2000) states that social benefits and functions are acquired through personal relationships with banking experts, while according to some other research, the determination and assessment of these benefits affects the user's satisfaction and this is also an important factor in driving users and sees their ability to apply internet banking. According to some theorists, consumer satisfaction has an impact and impact on user retrieval and acceptance rates on every newly introduced and innovative tool such as Internet banking application. According to Roger \& Shoemaker (1971) states that consumers prefer to collect knowledge and information about innovative products and services such as internet banking before using and adapting them. Guiltinard \& Donnelly (1983) explains the importance of awareness and knowledge related to any innovative products and services before using and adapting them.

Doll, Xia \& Torkzadeh (1999) argues that consumer satisfaction may be influenced by the nature and quality of information about the products displayed on the website. According to Steward (1999), among the failures in adapting Internet banking is due to the lack of customer confidence in internet banking. He thinks that consumer confidence and trust towards internet banking depends on the professional attitude and efficiency of banking experts. However, he advises consumers to develop new skills and expertise such as internet banking to enable users to understand and utilize and utilize the latest technological innovations.

According to Zaman (2016) states that research has been conducted in China related to the behavior and attitude of consumers towards internet banking. He concluded that there are several factors that demonstrate consumer attitudes towards internet banking including their perceptions of innovative technology, attitudes and motivation towards internet banking. The study found that knowledge and experience on relevant technology had an effective impact on the behavior and ability of users of internet banking. According to Octavian \& Daniela (2006) and Omar (2011) find that some users are unaware of internet banking services. However, banking users 
may use internet banking for the willingness to accept change and innovation and appreciate what bank had given.

4. Demographics Impact on the use of Internet banking

Users' demographic characters are one thing that also plays an important role in seeing factors that encourage users to adapt and use internet banking. According to previous studies, Demographics have impacted the use of internet banking. According to Howcroft et.al (2002), young consumers appreciate the convenience and time that saves the potential of online banking and mobile banking over older users. He argues that the level of respondents' education does not affect the use of internet banking. Laukkanen (2012), Capgemini (2013), Goh et.al (2014) found that younger, smarter users of technology placed higher importance on internet banking than traditional banking conducted face-to-face with banking experts. Karjaluoto et.al (2002) found that internet banking user criteria in the Finland market is educated, rich and young people and has good knowledge of computers, especially the internet.

Xiaoyan (2005) found that the majority of internet banking users in China is from men aged up to 44 years old and categorized from high-income groups. He argues that the level of respondents' education does not affect the use of internet banking in China. According to Crabble et.al (2009), demographic factors play an important role in making decisions on internet banking adaptation. They point out that social and cultural factors such as credibility, elitism and demographic factors are factors that affect individuals who make decisions on the use of Internet banking in Ghana. Davis (1989); Venkatesh \& Davis (1996); Vainio (2006) states that respondents who are influenced by facilitation do not need much knowledge. Mobarek (2007) states that internet banking is more popular and chosen by young people. However, Polasik \& Wisniewski (2008) emphasizes that parents aged 65 and above are not interested and refuse to accept internet banking.

The results of the analysis have shown that some of the surveys described by Teo et.al (2011) reveal that demographics and psychographics affect users to the use of technology as new innovations such as internet banking applications. In addition, analysis is conducted on demographic effects in the use of internet banking. Teo et.al (2012) also addresses demographic factors and subjective norms with technology adoption model (Technology Acceptance Model) founded by Fred Davis in 1989 to assess the level of adaptation of internet banking usage in Malaysia and proved that the model exists relates to the adaptation of the use of internet banking in Malaysia.

Goswani (2009) states that university students acquiring and using sophisticated cell phone equipment proved to be very interested in innovative use such as internet banking used by mobile phones. Similarly, reports from KPMG (2009) show that users aged 16-34 are the most comfortable age categories of internet banking especially through mobile phones for financial transactions and others while the 65-year-old respondents demographic proves that they are very uncomfortable with the use of Internet banking.

\section{Factor that Influence the adoption of Internet banking}

Jahangir \& Begum (2008) states that there are four identified factors that have influenced users in applying internet banking in Bangladesh. These factors include the perceived usefulness, perceived ease of use, privacy \& safety and individual characteristics which have significantly contributed to the user's use of internet banking. According to Polatoglu \& Ekin (2001) find that relative advantages, perceived risk and trialability where customer want to try a new services from the banks are factors that have influenced the spread and use of Internet banking in Turkey. The researcher also concludes that users using internet banking find that the banking is very helpful and facilitates users in conducting banking transactions.

According to Yousafzai (2005) states that there are many factors that have influenced users in adapting the use of internet banking. Among the factors that have prompted users to adopt Internet banking are perceived ease of use, perceived usefulness, perceived risk, perceived trust, privacy \& security and the behavior of users themselves want to apply for banking internet. According to Eriksson et.al (2005) the results of his analysis have proven that there are three factors that encourage consumers to choose Internet banking. Where perceived ease of use, perceived usefulness and trust have been the major factors affecting users choosing internet banking. According to Ramayah et.al (2006) found that the majority of consumers have been influenced by two major factors which prompted them not to use internet banking to use it. The factors that motivate them are the perceived usefulness and the behavior of their own users who take them to use the Internet banking.

Cheng et.al (2006) expands the Technology Acceptance Model to incorporate site safety factors considered to obtain factors that have influenced the use of internet banking in Hong Kong. His analysis shows that the intention to apply internet banking is influenced by perceived usefulness and web security. The results also show indirect effects on convenience factors that bring benefits to the use of internet banking.

Pikkarainen et.al (2004) uses a traditional Technology Acceptance Model founded by Fred Davis in 1989 and states that perceived ease of use and perceived usefulness are added with the privacy and security aspects of became an important factor related to the acceptance of Internet banking in Finland. Lin (2010) states that relative advantages, perceived ease of use, compatibility and integrity channels where acceptance of customer to change banking method that suggested by banks have influenced the decision to adopt internet banking services. 
In addition, Lee (2009) reports that the desire to use internet banking can be affected if privacy and security risks are positively affected positively can impact the benefits of internet banking acceptance. Uchenna et.al (2011) says that customers are influence by 6 factors which includes perceived ease of use, perceived usefulness, trust, relative advantage, trailability and individual characteristics. According to Sazili et.al (2014) states that there are two main factors affecting the user's application of internet banking is from the aspect of trust and security aspect.

Alex (2015) argues that there are a number of factors that have been expressed as factors that encourage consumers to choose internet banking but only two of the highest exemplary factors have influenced users to choose internet banking, perceived ease of use and privacy \& security. Ahmed (2016) says that perceived ease of use and usefulness plays an important role on influencing customer to use internet banking. He also states that a well-managed risk also helps attract customer to use internet banking.

Meanwhile, according to Zaman (2016) states that there are four factors that have influenced the consumers choosing Internet banking in Pakistan. These factors include perceived ease of use, perceived usefulness, perceptions towards risk and beliefs. Amola (2016) says that perceived ease of use is the critical factor that may influence customer to use internet banking as well as customer awareness towards internet banking also able to influence customer to use online services. According to Vasiliki (2017) proved that customers are influenced by two factor which is perceived usefulness and compatibility where customers are aware that internet banking gives variety of benefits and compatible to any kind of customers either retail or corporate customers. Table 1.0 shows the literature analysis on factors that influence the adoption of internet banking.

Table 1.Literature analysis on factor that influence the adoption of Internet banking

\begin{tabular}{|c|c|c|c|c|c|c|c|c|c|c|}
\hline \multirow{2}{*}{$\begin{array}{c}\text { Research } \\
\text { Analysis }\end{array}$} & \multicolumn{10}{|c|}{ Factor that Influence the Adoption of Internet Banking } \\
\hline & F1 & $\mathrm{F} 2$ & $\mathrm{~F} 3$ & $\mathrm{~F} 4$ & F5 & F6 & F7 & F8 & F9 & F10 \\
\hline Polatoglu \& Ekin (2001) & & 1 & I & & & I & & & I & \\
\hline Pikkarainen et.al (2004) & I & I & & & I & & & & & \\
\hline Yousafzai (2005) & 1 & I & I & 1 & I & & & & & 1 \\
\hline Eriksson et.al (2005) & 1 & 1 & & 1 & & & & & & \\
\hline Ramayah et.al (2006) & 1 & & & & & & & & & 1 \\
\hline Cheng et.al (2006) & 1 & I & & & 1 & & & & & \\
\hline Jahangir \& Begum (2008) & 1 & 1 & & & I & & & & & 1 \\
\hline Lee (2009) & 1 & & I & & I & & & & & \\
\hline Lewis et.al (2010) & 1 & & I & 1 & & & & & & \\
\hline Lin (2010) & & I & & & & & 1 & I & & \\
\hline Uchenna et.al (2011) & 1 & 1 & & 1 & & 1 & & & 1 & 1 \\
\hline Perkins (2013) & 1 & 1 & & 1 & 1 & & & & & \\
\hline Shazili et.al (2014) & & & & 1 & 1 & & & & & \\
\hline Alex (2015) & & 1 & & & 1 & & & & & \\
\hline Ahmed (2016) & 1 & 1 & 1 & & & & & & & \\
\hline Sohaib (2016) & 1 & 1 & I & 1 & & & & & & \\
\hline Amola (2016) & 1 & & & & & & & & & \\
\hline Vasiliki (2017) & 1 & & & & & & 1 & & & \\
\hline Total & 14 & 12 & 6 & 7 & 8 & 2 & 2 & 1 & 2 & 4 \\
\hline
\end{tabular}

This table above has listed a literature analysis from year 2001 until a recent 2017 regarding on factor that influence the adoption of internet banking. F1 means perceived usefulness, F2 means perceived usefulness, F3 means perceived risk, F4 means trust, F5 means privacy and security, F6 means relative advantage, F7 means compatibility, F8 means integrity channels, F9 means trialability and F10 means Individual characteristics. According to the researcher, there are 10 main factors that influence customers to use internet banking because Internet banking provides many facilities and benefits to consumers in conducting financial transactions. With the ease of technology, consumers can run financial transactions easily and quickly. Overall, the majority of literature proved the factors that drive users to choose Internet banking are consisted of perceived usefulness and ease of use factors. Both of these factors are factors originated from the theory of technology acceptance model founded by Fred Davis in 1989 and yet still proved able to influence customer to use internet banking.

6. Conclusion

This literature reviews has proven that there are 10 main factors that encourage users to apply internet banking. The study found that there were two major factors that greatly affected the users of internet banking. Perceived ease of use and usefulness has positively affected the acceptance of internet banking. This may be related to the 
fact that the majority of respondents who interested in internet banking are also among young adults who tend to be more exposed on internet than respondents of other age categories. The fact is also proved that there is a demographic impact that encourages consumers to choose internet banking. The results of this literature study also point out that the perceived usefulness is also one of the highest factors that have affected users using internet banking. The perception of the benefits and uses of this factor is an assessment of how far someone believes that certain system applications can improve the performance of a job. The findings show that respondents are interested in the advantages of the system and offer for relative advantages to other systems because the advantages of the system can be used anytime and anywhere. Therefore, the results of this analysis proved that the theory of technology acceptance model founded by Davis plays an important role in encouraging consumers to apply internet banking.

\section{Recommendations}

Internet banking is a technology utilized in a worldwide banking system including Brunei Darussalam itself. In addition to emphasizing the issues that affect users in receiving internet banking, then any several issues that can be problematic should be addressed. Among the things that can be emphasized is conducting research on the ability of consumers to accept banking and the demographic continuity of the use of internet banking in Brunei Darussalam because previous research has proven that there is a demographic impact that affects consumers from receiving Internet banking. Suggestions for future researchers are also to conduct an analysis of the user's ability to avoid from using internet banking. The next researcher can also relate the age level and education background to see the demographic gap that differentiates the level of consumer applications that choose internet banking and which avoids internet banking.

References

Ahmed, E.M. (2016). Factor that Influencing the Adoption of Internet Banking in Malaysia. Journal of Internet Banking and Commerce. 21(1). 1-28.

Bhatt, A. (2016). Factor affecting Customers' adoption of Mobile banking services. Journal of Internet Banking and Commerce. 22(1).

(2013). Consumer taking charge, consumer and convergence III. KPMG International.

Capgemini. (2013). World retail banking report. European Financial Management and marketing association.

Cheng T, et.al. (2006). Examination of attitudes towards teaching online courses based on theory of Reasoned Action of University faculty in Taiwan. British Journal of Educational Technology. 683-693.

Crabble, M., Standing, C., Standing S. \& Karjaluoto H. (2009). An Adoption model for mobile banking in Ghana. International Journal of Mobile Communication. 7(1). 515 - 543.

Doll, W.J., Xia W. \& Torkzadeh G. (1994). A confirmatory factor analysis of the end-user computing satisfaction instrument. Mis Quarterly. 453 - 461.

Driga I. (2014). E-Banking services: Features, challenges and benefits. International Journal of Internet banking and commerce. 49-58.

Eriksson, K., Kerem K. \& Nilsson D. (2008). The adoption of commercial innovations in the former Central and Eastern European markets. The case of internet banking in Estonia. International Journal of Bank Marketing. 26 (3). 154-69.

Fred, D. (1989). Perceived Usefulness, Perceived Ease of Use and user acceptance of Information Technology. MIS Quartely. 319-340.

Goh, T.T., Suki, N.M. \& Fam K. (2014). Exploring a consumption value model for Islamic mobile banking adoption. Journal of Islamic Marketing. 5(1). 344 - 365.

Guiltinand, J.P \& Donnelly, J.H. (1983). The use of product portfolio analysis in bank marketing planning. Management issues for financial institutions 50.

Heinonen, K. (2007). Conceptualizing Online banking service value. Journal of Financial services marketing. 39-52.

Howcroft, B., Hamilton \& Hewer P. (2002). Consumer attitude and the usage and adoption of home-based banking in the United Kingdom. International Journal of Bank Marketing. 20(1). 111 - 121.

Jahangir, N. \& Begum, N. (2008). The role of Perceived Usefulness, Perceived ease of Use, Security and Privacy and Customer attitude to engender adaptation in the context of Eletronic banking. African Journal of Business Management. 32 - 40.

Karjaluoto, H., Matilla, M. \& Pento, T. (2002). Factors underlying attitude formation towards online banking in Finland. International Journal of Bank Marketing. 20(1). 261 - 272.

Koksal, M. H. (2016). The intentions of Lebanese Consumers to adopt mobile banking. International Journal of Bank Marketing. 34(3). 556-568.

Laforet, S. \& Xiaoyan, L. (2005). Consumers' attitudes towards online and mobile banking in China. International Journal of Bank Marketing. 23(1). 362 - 380 
Laukkanen, T. \& Cruz, P. (2012). Cultural, Individual and device-specific antecedents on mobile banking adoption: a Cross-national study. Proceedings of the 45th IEEE Hawaii International Conference on System Sciences (HCISS). Hawaii.

Laukkanen, T. (2007). Internet vs Mobile Banking: Comparison customer value perception. Journal of Business process management. 788-797.

Lee, M. (2009). Factors influencing the adoption of internet banking: An integration of TAM and TPB with perceived risk and perceived benefit. Electronic Commerce Research and Applications. 8(3). 130-141.

Lin, H. F. (2010). An empirical Investigation of Mobile banking adaptations: The effect of Innovation attributes and Knowledge-based Trust. International Journal of Information and Management. 31(1). 252 - 260.

Maitlo, G.M. et al. (2015). Factor that influence the adoption of Online banking services in Hyderadab. International Journal of Economics \& Management Science. 1-10.

McKechnie, S., Winklhofer, H. I. \& Ennew, C. (2006). Applying the technology acceptance model to the online retailing of financial services. International Journal of Retail and Distribution Management, 34(4). 388-410.

Mekter, et.al. (2003). Factor affecting the adoption of mobile banking services. Journal of Internet banking and Commerce. 8(1). $89-101$.

Melek, et.al. (2010). An Evaluation of Internet banking in Turkey. Journal of Internet banking and Commerce. 15(2). 1-25.

Mobarek, A. (2007). E-Banking practices and customer satisfaction: A case study in Botswana. Botswana.

Octavian, D. \& Daniela, P. (2006). The Adoption of Electronic Banking Services in Developing Countries - The Romanian Case. Journal of Internet banking and Commerce. 1-16.

Oliveira, T. et.al. (2014). Extending the understanding of mobile banking adoption: When UTAUT meets TTF and ITM. International Journal of Bank Marketing. 34(5). 689-703.

Omar, A. et.al. (2011). Customer Perception towards Online Banking Services: Empirical Evidence from Pakistan. Journal of Internet Banking and Commerce. 16(2).

Pace, D. (2016). Customer's perceptions towards online banking services in Malta. Valleta, Malta: University of Malta.

Peter, A. A. O. (2015). Factor affecting the adoption of Internet banking in Nigeria. E-theses. Eastern Mediterannean University Cyprus.

Pikkarainen, et.al. (2004). Consumer acceptance of online banking: an extension of the Technology Acceptance Model. Journal of Internet Research. 14(1). 224 - 235.

Polasik \& Wisniewski, M. (2009). Empirical analysis of Internet banking adoption in Poland. International Journal of Bank marketing. 32-52.

Polatoglu, V. N. \& Ekin, S. (2001). An empirical Investigation of the Turkish consumers' acceptance of Internet banking services. International Journalof Bank Marketing. 156 - 165.

Raghavendran, G. (2009). Mobile banking: Can elephants and hippos tango? Journal of Business strategy. 1420.

Ramayah et.al. (2006). User acceptance of Internet banking in Malaysia: Test of three computing Models. International Journal of E-adoption. 1(1). 1 - 19.

Reynolds, K.E. \& Beatty, S.E. (2000). A relationship customer typology. Journal of Retailing. 75(1). 509 - 523.

Roger, E.M. \& Shoemaker, F. (1971). Communication In Innovation. New York USA. Free Press.

Sazili, S. et.al. (2014). Factor that influence Internet banking adoption among Postgraduate students. International Journal of Innovative Research in computer science \& Technology. 22-27.

Shaikh, A. \& Karjaluoto, H. (2016). Mobile banking adoption: A Literature review. Journal of Telematics and Informatics. 32(1). 129-142.

Steward, K. J. (1999). Transference as a means of building trust in World Wide Web sites. 20th International conference proceedings on Informations Systems. 459 - 464.

Teo, A. et al. (2012). Can the demographic and subjective norms influence the adoption of mobile banking? International Journal of Mobile Communication. 10(1). 578 - 597.

Uchenna, C. E. et al (2011). Factors affecting Internet Banking adoption among Young Adults. International conference of Social Science and Humanity. 377 - 381.

Vainio, H. M. (2006). Factor influencing corporate customers' acceptance of Internet banking: A Case of Scandinavian trade finance. E-theses. The Swedish School of Economics and Business Administration.

Vasiliki, K. (2017). Factor influencing the adoption of Internet banking in Greece. E-theses University of Greenwitch Greece.

Venkatesh, V. \& Davis, F. (1996). A model of antecedents of perceived ease of use: A Development and test. Journal of decision Science. 27. $451-481$.

Yousafzai. S. (2005). Customer behaviour towards Internet banking. Cardiff United Kingdom: Cardiff Business school Cardiff. 
Zaman, S. U. (2016). An Investigation into Prime Issues impeding the adoption of Internet banking in Pakistani firms and Organisations. Journal of Internet banking and Commerce. 1(1). 1 -14.

\section{Copyrights}

Copyright for this article is retained by the author(s), with first publication rights granted to the journal.

This is an open-access article distributed under the terms and conditions of the Creative Commons Attribution license (http://creativecommons.org/licenses/by/4.0/) 